\title{
Investigations of a journalistic blind spot
}

\author{
Class, constructors, and carers in Norwegian media
}

\author{
Tine Ustad Figenschou, Elisabeth Eide, \\ \& Ruth Einervoll Nilsen \\ Department of Journalism and Media Studies, Oslo Metropolitan University, Norway
}

\begin{abstract}
Recent studies argue that the contemporary working class has largely disappeared from the news media. Another strand of literature demonstrates that the traditional labour beat has lost newsroom prestige due to changes in the established news media and crisis in the labour movement. Analysing how traditional working-class sectors are covered in mainstream newspapers and trade union magazines over time, we conduct a systematic, quantitative content analysis of 18 months of coverage from 1996-2017. We find a steady decline in media coverage throughout the period, indicating that the labour beat as an established specialisation is disappearing. Studying topical emphasis and source practices demonstrates marked differences between the newspapers and the trade union magazines: The mainstream newspapers are elite- and conflict-oriented (although not hostile in their coverage), while the trade union magazines largely reflect power structures and the interests of the labour movement. In the discussion, the main findings from the content analysis are explained by practitioners, to contextualise and provide insider perspectives on the findings.
\end{abstract}

Keywords: journalism and working class, despecialisation, marginalisation, trade union magazines

\section{Introduction}

Both media scholars and the media industry have largely ignored social class as a relevant analytical concept (but see Hesmondhalgh, 2017; Jakobsson \& Stiernstedt, 2018; Lindell, 2018), reflecting declining class awareness in academic and popular debates (Biressi, 2018; Yilmaz, 2018). Politicisation of the working class in recent years has served as a wake-up call that has initiated new interest in the modern working class, both within newsrooms and among politicians and researchers (Martin, 2019). Recent studies of class division and representation find that working-class people are both underrepresented and misrepresented (Hesmondhalgh, 2017), subject to mediated marginalisation by being represented as less important than people from the middle or upper classes (Stiernstedt \& Jakobsson, 2018). Critical scholars interpret this as neoliberal journalistic discourses on industrial workers in the Nordic and global contexts

Figenschou, T. U., Eide, E., \& Einervoll Nilsen, R. (2021). Investigations of a journalistic blind spot Class, constructors, and carers in Norwegian media. Nordicom Review, 42(S3), 71-87. https:// doi.org/10.2478/nor-2021-0027 
(Jacobsson \& Ekström, 2016; San Martin, 2019). Furthermore, international studies of labour reporting find that the news media today primarily look at the working class through the lens of a political news story, not as a labour or workplace story (Bjerke \& Fonn, 2016; Martin, 2019).

Studies of media coverage of the labour movement (for a comprehensive overview, see Manning, 1998) find that the labour issue and movement gradually lost media visibility following its high point in the 1970s (Bekken, 2005), and that the established news coverage gradually became more critical of the movement (Costain, 2005). Moreover, analysis of the practices, expertise, and status of labour reporters documents a devaluation of the labour beat from the 1980s onwards (Manning, 1998). These international studies offer a point of departure for the present article, which zooms in on the news media and trade union press coverage of two traditional working-class sectors in Norway - the construction sector and the care sector - over a period of 20 years. We selected these sectors for analysis because they represent typical working-class sectors, but also because they are strongly gendered, workers with migrant backgrounds are amply represented, and many workers hold particularly vulnerable positions.

As far as we know, systematic content analysis has not been conducted on the coverage of the construction and care sectors in Norwegian media over time. Most international studies of the labour beat largely focus on the period until the mid-1990s and do not provide insight into the wide-ranging changes in the media landscape in recent decades (e.g., Manning, 1998). Furthermore, existing studies have largely studied labour reporting in neoliberal systems such as the UK and US, while we have limited insight into how labour reporting has developed in social democratic systems where corporatism has remained relatively strong (for further discussion, see Bjerke, 2016). Moreover, studies generally analyse the established news media, while there has been remarkably few studies of the trade union press (cf. Grace, 1985). Mapping changes in the scale of coverage, the topical emphasis, and the source patterns in both mainstream news and trade union press from 1996/1997-2016/2017, this article adds to the scholarly discussion and illuminates the dramatic changes in "the labour beat" as a journalistic specialisation in Norwegian newspapers and trade union magazines. Since our broader aim is to study labour reporting and media representation of the working class, we first analyse how and to what extent the key stakeholders in the labour beat are represented, and, second, to what extent the workers in the construction and care sectors are included as news sources.

\section{Analytical framework: From labour beat to journalistic blind spot?}

Theoretically, we situate this article in literature on media marginalisation, voice, and mediated representation. We employ this lens by analysing how the professionalisation, routinisation, and eventually (de)professionalisation of labour reporting affects media representation and the voice of the working class. The professionalisation and thematic specialisation in journalism - what is labelled beat journalism - is often seen as a response to the growing differentiation of society (Magin \& Maurer, 2019). Organising news production between specialised beat reporters, general assignment reporters, and desk editors increased the efficiency of journalistic work and helped news organisations structure the news agenda, fill the paper, plan ahead, and make the news flow predictable (Magin \& Maurer, 2019). 
From international studies of the labour beat, we know that in the 1960-1970s, labour reporting was considered a prestigious beat, regarded as highly newsworthy within established newsrooms (Bekken, 2005; Costain, 2005; Manning, 1998; Martin, 2019). In Norwegian newspapers, it was a regular beat with specialised labour correspondents, from the early 1900 s to the late 1980 s, although newsroom commitment to the labour beat became more ambivalent from the 1990s onwards (Bjerke, 2016; Mathisen, 2013). This may be related to a gradual shift in political developments from the early 1980s to more market-oriented politics, where sectors such as electricity, telephone, and housing were liberalised (Bjerke \& Fonn, 2016). This liberalisation was the result of a tacit political consensus between the main political parties, a development that moved the coverage of the sectors to business journalism rather than political journalism (Bjerke \& Fonn, 2016). The shift has led some scholars to characterise the media as "cornerstones of the neoliberal construction" (Jacobsson \& Ekström, 2016: 380).

A beat represents a special set of routines and sources, as particular beats often grant privilege to a particular set of news sources and actors (Magin \& Maurer, 2019). News sources have strong interests in influencing news coverage, and a rich body of literature has theorised the reporter-news-source relationship. The pioneering systematisation of media access finds that official sources, associated with the government and the state, enjoy crucial advantages in the competition for news access. Theorising how privileged elite access influences mediated debates, authoritative studies find that the range of viewpoints voiced in the media largely reflect internal variation in elite consensus and disagreement, generally not capturing initiatives outside these elite circles (Bennett, 1990; Hallin, 1986/1989; Hall et al., 1978; Manning, 2001).

A number of studies of specific journalistic beats have analysed how reporter routinisation of journalistic work contributes to the priorities of "safe" sources known to "deliver"; production pressures thus render journalists more dependent on their established source network (Phillips, 2010: 100). The more professional and authoritative the sources are, the greater their chance of having an influential voice (Berkowitz, 2009). For labour reporters, three groups represented "safe" elite sources: the employers and managers; the unions and labour movement; and the state (most often the ministry of labour) (Manning, 1998). These actors' in-house publications (including labour press magazines) and public statements (e.g., press briefings, conferences) represent the formal information sources available to labour correspondents (Manning, 1998). More importantly, however, labour correspondents built extensive source networks within these organisations, had frequent informal meetings, and gained contextual understanding and expertise, securing their position in the newsroom hierarchy (Manning, 1998).

From a class representation perspective, it is worth noting that the labour beat was highly routinised, elitist, and oriented around managers, union leaders, and politicians in the power centre or capital. Regular workers, ordinary union members, or ordinary people outside these circles were rarely given a voice in the coverage (Manning, 1998). Although labour correspondents have largely been supportive of the labour movement (Costain, 2005), they held a prestigious position in the newsroom, primarily because of their connections to powerful actors and political affairs (Manning, 1998). Ordinary workers were most often included as examples (cases) in labour stories (often recruited by the union communication staff to promote their cause), and thus the workers' experiences were most often rendered invisible or peripheral - what is often labelled symbolic 
annihilation (Gerbner \& Gross, 1976; see also Tuchman, 1978). In practice, marginalised groups are often represented by proxy in mediated debates, other news sources higher up in the news hierarchy speak on their behalf as a substitute for their own voices (Eide, 2011; Tvedt, 2003). In labour journalism, labour union representatives have been the formal and symbolic proxy representation of ordinary workers, although the distance from union elites to unskilled workers should be noted, and falling unionisation rates indicate that many workers remain outside such organised interests.

From the 1980s onwards, the labour beat was weakened as, internationally, labour movements largely lost their political momentum due to radical changes in political and economic structures (for full analysis, see Manning ,1998; Martin, 2019). Dramatic changes in the news media landscape exacerbated the political and ideological marginalisation of the labour movement. Media ownership became more commercially driven, pushing newsrooms to emphasise tabloid news criteria such as conflict, sensation, political celebrity, and personalisation (Manning, 1998). The beat-journalism model largely disintegrated, pushing most reporters into all-round positions, while the most ambitious reporters increasingly flocked to the political or finance beats (Magin \& Maurer, 2019; Manning, 1998; Martin, 2019). Since the labour beat studies of the 1990s, technological disruption and networked social media platforms have intensified the competition for attention, audiences, and advertisement. Consequently, as a result of falling revenues and failing business models in contemporary news media, there has been a strong push towards cost-effective, popularised production (Karidi, 2018), giving rise to discussions of deprofessionalisation and deskilling in contemporary journalism (Gollmitzer, 2019).

These developments influence the daily labour-beat practices (and all other reporters), as there is less time and resources to meet sources face to face. Manning (1998) describes how increased production pressure and the downscaling of newsrooms gradually restricted regular meetings between labour correspondents and their personal source networks and confined reporters to their desks. Furthermore, professionalised communication officials representing employers, unions, and the government both centralised and professionalised what kind of information was made available. Since the 1990s, these developments have intensified, as the current news landscape - characterised by 24/7 multimedia news cycles - has speeded up news cycles and increased workloads for journalists, pushing for more routinised sourcing practices and more reporting in front of the computer (Maurer \& Magin, 2019). Existing studies find that although online sources complement traditional sourcing for journalists largely bound to desks and laptops, journalists still select elite sources ahead of ordinary people (for systematic review, see Lecheler \& Kruikemeier, 2016).

Building on existing studies of mediated class representation, labour journalism, and journalistic beats, the present study has an exploratory overarching research question: What characterises the coverage of the construction and care sectors in Norwegian established news and trade union press, and how does the coverage develop over time? This overarching question is investigated through three sub-questions:

1. To examine to what extent we find declining news interest in labour affairs (represented through two traditional working-class sectors) in Norwegian established news and trade union press over the period studied, we ask: How salient are the classic working-class sectors in the media over time? 
2. To illuminate whether the coverage has become more conflict oriented and critical over time, reflecting a tabloidisation thesis, we ask: How are the construction and care sectors represented in the media over time?

3. To examine whether the sourcing practices seem to be increasingly elite-oriented, routinised, and desk-bound, we ask: Who is invited to speak about care and construction in the media over time?

\section{The Norwegian context}

From an international perspective, Norwegian social democracy is comparatively egalitarian: The distance between societal and political elites and the general public is smaller than in many other countries, and it is easier for organised interests and the media to approach politicians (Ihlen et al., 2015). The work-life policy area is characterised by a distinct tripartite dynamic involving key players in society, including employer organisations and unions. In the Nordic countries, these actors have traditionally belonged to a corporatist system where organised interests have voiced and represented their interests through formal insider representation, for example public policy committees (see, among others, Rommetvedt, 2017).

As described in international media systems literature, the Norwegian media system represents Hallin and Mancini's (2004) democratic corporatist model. In a recent, largescale empirical reevaluation of their media system theory, Brüggemann and colleagues (2014) argue that the Nordic media model represents a distinct cluster of countries, characterised by highly professional journalism, an inclusive press market, powerful public broadcasting, and generous press subsidies, in combination with low levels of ownership regulation and low levels of political parallelism. In line with this, Syvertsen and colleagues' (2015) media welfare state model illustrates how Nordic media policy and strong public service broadcasters have made communication and media universally available, and, consequently, social class has been less of an issue. More recently, Lindell (2018), who identifies systematic class-based differences in news consumption in the Nordic region, has questioned this egalitarian media welfare state model.

Throughout the period studied in this project, broader international disruption in the media landscape - such as declining revenues and increasing global and digital competition - has caused an unprecedented decline in readership and newspaper circulation, which is also the case in the Nordic region (particularly among young people and people from lower socioeconomic strata). Additionally, advertisement sales are lower, the strong position of the press has been weakened (Ohlsson, 2015), and there are fewer jobs for journalists in the Norwegian system (Kalsnes \& Steensen, 2020). Norwegian paid-print circulation has been severely weakened, although the local, regional, and niche press is still relatively strong; established news organisations remain dominant players in digital news, and there are relatively few digital stand-alones (Allern \& Pollack, 2019). In Norway, commercialisation has primarily taken place through the transformation of existing newspapers, a development that has accelerated as circulation has declined (Eide \& Knight, 1999). Such commercialisation processes often involve emphasising tabloid news criteria and perceiving the audience primarily as consumers (Eide \& Knight, 1999). Over the same decades, the Norwegian union press has undergone what can be 
characterised as a process of professionalisation, from being a union mouthpiece to a more editorially independent position, as members of professional associations which adhere to the code of ethics (Kalsnes \& Steensen, 2020), although they are still owned by the unions, and union members are their target audiences.

\section{Method}

This analysis is part of a broader interdisciplinary research project studying the contemporary working class, with a particular focus on the ethnic composition and internal relations within the working class, and between workers and broader society. The two working-class sectors studied comprise both skilled workers (e.g., auxiliary nurses, electricians, and carpenters) and unskilled workers (e.g., assistants). Critics find that working conditions in both sectors are increasingly characterised by temporary staffing, subcontracting, and deskilling (construction - see Haakestad \& Friberg, 2020) and increased workloads, shorter contracts, lower salaries, and inconvenient working hours, particularly for labour immigrants (care sector - see Bohlin, 2012). These occupational sectors have also been selected because they remain highly segregated by gender at the same time as they are ethnically diverse. Although Norway is one of the most equal countries in the world, the labour market is still notably gender-segregated, particularly in working-class sectors (Orupabo, 2016). In essence, the care sector is largely female, and the construction sector is largely male. Furthermore, the two sectors have high proportions of workers with ethnic minority backgrounds due to labour migration (particularly after the EU enlargements in 2004 and 2007), and migrant workers have lower unionisation rates (Haakestad \& Friberg, 2020). Thus, a wider intersectional analysis (Crenshaw, 1989; Gressgård, 2008) would ideally have been part of this article; however, due to format constraints, the empirical findings will be included but not discussed at length.

A sample of five national newspapers (one including a weekend supplement) was selected for analysis, representing a spectrum of political positions ranging from Aftenposten (liberal-conservative broadsheet newspaper), ${ }^{1}$ Dagens Nceringsliv (conservative business paper), $V G$ (tabloid newspaper), Arbeiderbladet/Dagsavisen (left-leaning labour press), and Klassekampen (left-leaning socialist press) was selected for this quantitative content analysis (Krippendorff, 2018). The party press system was largely abolished in the late 1970s, but the newspapers are still largely associated with their political affiliations. In addition, because the labour press has traditionally been an important player for the labour beat, the two largest trade union press magazines that cover the sectors studied Fagbladet and Magasinet for fagorganiserte - are included in the analysis. Articles were selected based on keyword searches in the national Norwegian media archives, Retriever, by combining all regular terms used to describe the workers in the two sectors (e.g., construction, builder, carpenter, bricklayer, auxiliary nurse, health care worker, health care assistant, etc.) in order to be as exhaustive as possible. ${ }^{2}$ The 1996/1997 and 2006/2007 editions of the trade union magazines were not included in the media archive and were therefore sampled manually by a research assistant. The article searches were conducted in three phases, covering a period of six months in the years 1996/1997, 2006/2007, and 2016/2017 (the third quarter of 1996, 2006 and 2016, and the first quarter of 1997, 2007 and 2017). Three research assistants then vetted the search results for relevance, and only 
the articles covering the two sectors were included in the sample (a total of 834 articles: 412 from the construction sector and 422 from the care sector).

The sample comprises stories about these two sectors from all news sections of the selected media (including national news, culture, foreign news, and the weekend and magazine sections). To examine changes in media attention, attitudes, and topical emphasis, we use a quantitative content analysis mapping a range of variables. First, to study the salience of the issue, we analyse the coverage over time (news medium, format, size, and whether the sectors were the main topic). Second, to determine whether the coverage has become more critical in its coverage of the workers and more conflict oriented, we analyse whether the workers are portrayed negatively or positively, as well as the topical focus of the news coverage. Third, we examine who is given a voice in the coverage by mapping the news sources. News sources are operationalised as the individuals quoted directly in the news items or who have written op-ed pieces. The first six news sources were registered for each news item, and each source was categorised by institutional affiliation, gender, and ethnic background. As only a few articles contain more than four sources, our source analysis includes up to four sources per article - 1,389 quoted news sources altogether. A team of three research assistants collected and analysed the empirical data after extensive training. A sample of 10 per cent of the articles $(N=81)$ were recoded to test inter-coder reliability. Inter-coder reliability scores (Cohen's kappa) ranged from 0.71 to 0.92 , with an average kappa score of 0.85 , which is a satisfactory level of inter-coder reliability. ${ }^{3}$

To illuminate the findings from the content analysis, we further refer to a supplementary study in which we interviewed the news editors or editors in the seven outlets analysed. In these focused, qualitative interviews conducted in 2019, we asked the editors to reflect on their labour reporting, class awareness, and the current state of the labour beat in their respective newsrooms. Analysed in full elsewhere, insights from the interviews are included in the final discussion to illuminate the main trends from the content analysis (for details, see Eide \& Figenschou, 2021).

\section{Results}

\section{Newsworthiness: How salient are the classic working-class sectors?}

Based on existing studies of labour journalism and the changes in the journalistic beat system, we wanted to map the media attention given to two working-class sectors over time. First, corresponding with earlier studies, we find that care and construction receive markedly less attention over the period studied (see Figure 1). In the mainstream news media, the decline is steady and continuous, while the development is less clear in the trade union press magazines, although the general tendency is clear. Furthermore, we find that although there are fewer stories in recent years than ten and twenty years ago, the sectors are more prominently present in the newer coverage than in the first periods. Similarly, when mapping article length, we find that articles are longer in the most recent sample (2016/2017) than in the previous years (2006/2007 and 1996/1997), where articles were generally shorter. Mapping whether the coverage stems from news agencies or in-house journalism is another indication of editorial prioritisation, and here we find that about one in five mainstream news stories are agency material, while the union press magazines studied fully rely on their in-house coverage throughout the period. 
Figure 1 News salience for care and construction sectors, 1996/1997-2016/2017 (number of stories)

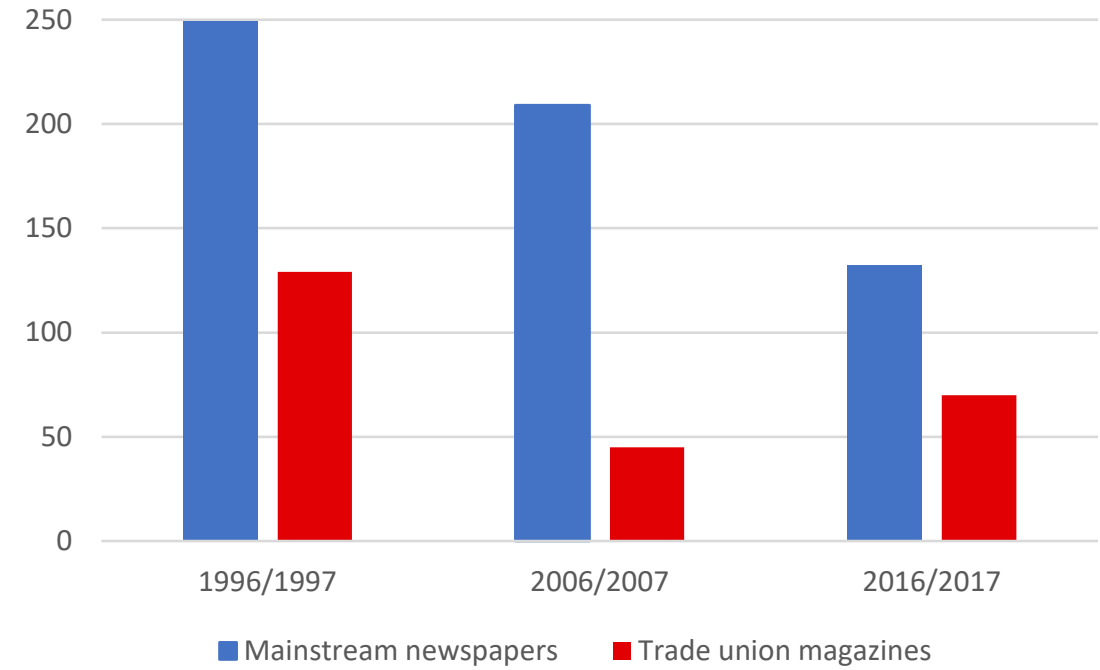

Comments: $N=834$ ( 412 from the construction sector and 422 from the care sector). Five national newspapers and two union press magazines were included in the sample. The examined content was published during a constructed six-month period (content published during the third quarter of 1996 and content published during the first quarter of 1997 form the sample for1996/1997; the merging logic is the same for 2006/2007 and 2016/2017).

Salience can also be studied by mapping news formats, since some genres, such as news reportage and features, are generally more prestigious and demanding of resource than news briefs and standard news articles. Additionally, the extent to which a topic is covered in news formats or opinion formats may provide an indication of how prominent a topic is on the public agenda. Both in the national newspapers and the trade union press, the working-class sectors are primarily covered as news - about seven out of ten articles published are news stories (51\% news articles and 17\% news briefs). There is some variation over time with respect to genre and news format, particularly in the mainstream newspaper coverage, where the number of feature stories falls drastically (from 34 to 2), at the same time as op-ed pieces by external writers almost doubles (from 25 to 46 ) in the time period studied.

\section{Topical emphasis: How are the construction and care sectors represented?}

Dramatic developments in both the media sector (higher production pressure, falling revenues, and stiffer competition) and the sectors studied (deskilling, precariousness, labour migration, and de-unionisation) suggest that the working class will be covered in more negative and conflict-oriented formats today than in previous decades (e.g., Manning, 1998).

In our study, we do not find such clear tendencies towards critical, conflict-oriented coverage. First, mapping the topical emphasis in the coverage (operationalised as the main topic of each article), we find that three main topics dominate the aggregated data. The most-covered topic comprises stories concerning working conditions (e.g., addressing negotiations, collective wage settlements, working hours, labour organisations, and workers' rights). Another topic that receives considerable attention is stories on work-related conflicts (e.g., conflicts between professions in the workplace or between 
employer and employee; stories about discrimination, exploitation, social dumping, and fraud; and stories about protests, strikes, or court cases). Work-related conflicts were frequently discussed in opinion formats, particularly concerning the consequences of labour migration in the construction sector. ${ }^{4}$ The third main topic is that of recruitment to the care and construction sectors (e.g., apprenticeships and practical training; continuing education and capacity building, as well as restructuring the workforce; reduced status of working-class occupations, recruitment problems, and initiatives to turn this negative trend). This topic has become particularly salient in recent years (2016/2017), as part of the broader ongoing public debate on craftsmanship, social class, and higher education, including debates on the status of the contemporary working class.

Topics such as labour policy and articles on how workers from these sectors contribute to society receive some attention throughout the period, whereas issues regarding technology, workplace equality, or workplace accidents are barely covered. Although some topics are emphasised in both mainstream newspapers and the labour union press, there are noteworthy differences in topical emphasis between the trade union magazines and the mainstream newspapers, as the trade union magazines, as expected, have a stronger emphasis on working conditions and recruitment, while stories on work-related conflicts and (more surprising) labour policy stories receive markedly less attention (see Figure 2).

Figure 2 Main topics in mainstream newspapers and trade union magazines, 1996/19972016/2017 (per cent)

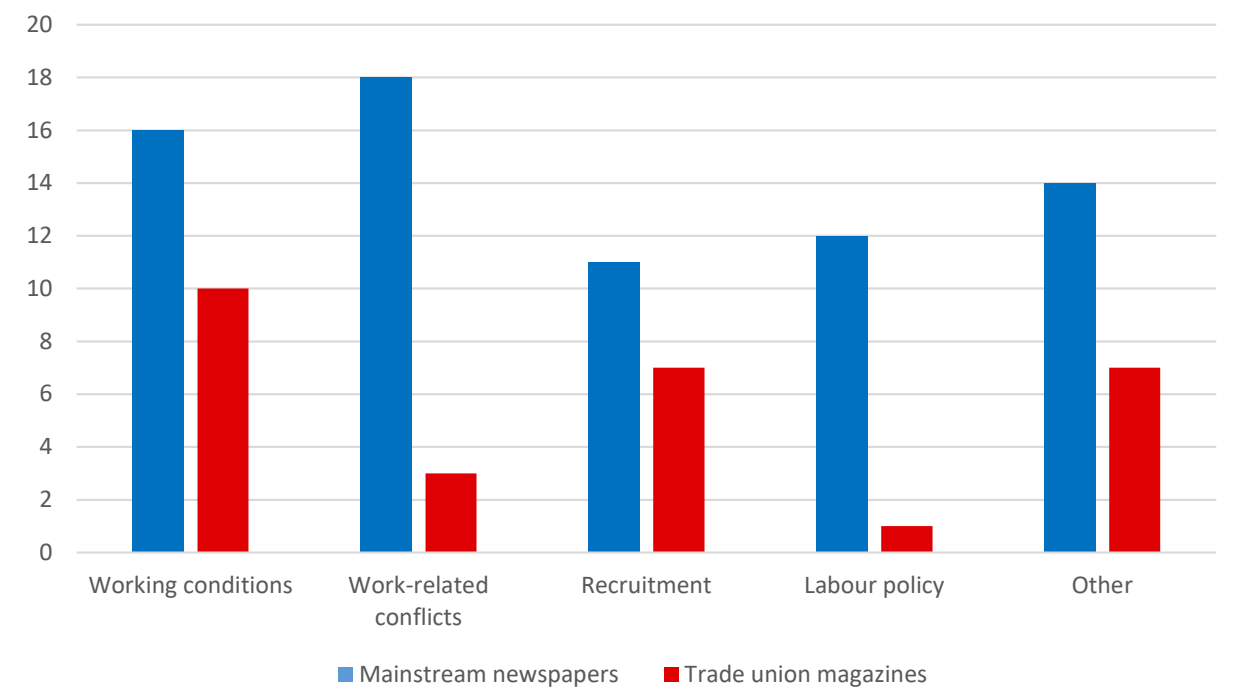

Comments: $N=590$ (newspapers) and 244 (trade union magazines). "Other" comprises topics that are rarely covered (like contribution to society, technology, workplace equality, workplace accidents, etc.) and articles that address topics not covered in the analysis.

Beyond the topics highlighted, we further analyse how construction workers and care workers are portrayed - more precisely whether they are presented in a neutral, positive, or critical light. Perhaps unsurprisingly, the overarching finding is that workers are featured in a neutral, balanced manner in most of the coverage ( $86 \%$ of all stories), and there is a slight decrease in critical portrayals of the workers over time. Moreover, as expected, the trade union magazines have a more positive representation of the workers 
than the national newspapers studied, which reflects that the union members are also their primary target audience.

\section{Source hierarchies: Who is invited to speak about care and construction?}

Overall, the traditional stakeholders on the labour issue - union representatives $(22 \%)$, political authorities (politicians and bureaucrats; $22 \%)$, and employers (14\%) - represent more than half of all the interviewed sources, indicating that the source hierarchies of the labour beat are still relevant (see Figure 3). At the same time, the different editorial agendas of the mainstream newspapers and the union press are evident in sourcing practices. In the trade union press magazines, workers and union representatives make up the majority of the sources interviewed, demonstrating that the union press is still first and foremost an outlet for and about the labour movement, whereas mainstream newspapers use traditional key stakeholders representing the labour-beat elite - such as union representatives, employers, political authorities - as the most important sources.

Figure 3 Sources quoted in mainstream newspapers and trade union magazines (per cent)

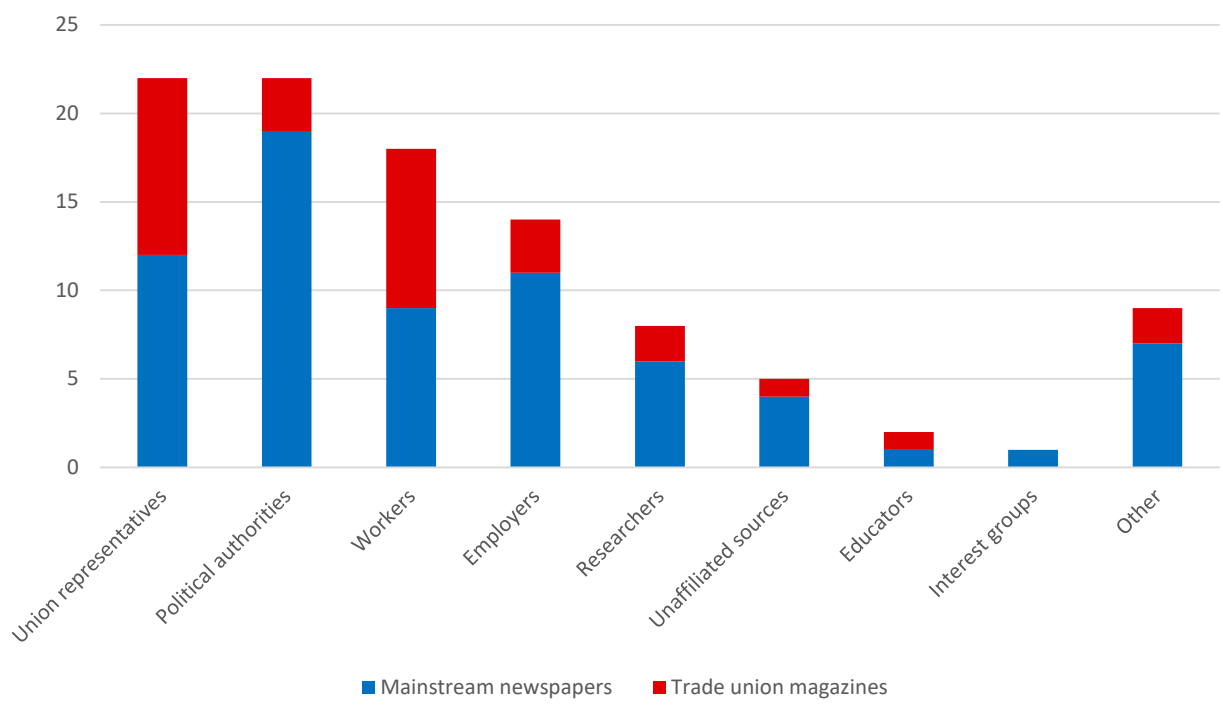

Comments: Percentage of total number of news sources (people quoted in the articles). $N=1,389$.

Overall, workers constitute almost one of five news sources quoted in the labour coverage (18\%). Arguably, workers' voices can also be represented by union representatives (who are elected representatives at the workplace level or higher), which comprise just over one-fifth of the quoted sources $(22 \%)$. As union representatives are elected to speak on behalf of workers' interests, local representatives may, in many cases, be interviewed instead of the workers. At the same time, not all workers are union members, and membership numbers are falling. Together, the workers themselves and the elected, professional representatives of workers' interests (union representatives) comprise 40 per cent of the sources, which is a substantial proportion. 
As the coverage of the construction and care sectors declines throughout the period studied, so too does the total number of sources - including workers. The relative distribution of sources remains, however, stable throughout the period studied, and there is no clear development towards increased elite orientation over time, a pattern that nuances studies of sourcing practices from other journalistic fields (see Philips, 2010).

Since the amount of coverage of the two sectors is equally divided, and we know that the sectors are male and female dominated, respectively, it is interesting to study the gender divide. Overall, 41 per cent of all the sources quoted are women, which is a markedly higher number of female sources than in most studies of general news coverage. The gender divide is not equally distributed between the different types of sources, however, as more female sources speak from a position as workers, union representatives, interest groups (organised interests that are not trade unions), educators, unaffiliated sources ("ordinary people" quoted without mentioning institutional affiliation), and "other" sources (see Figure 4).

Female sources are particularly underrepresented as representatives of the elite sources (employers, political authorities, and researchers). This supports earlier findings (Eide \& Orgeret, 2015) about journalism's elite orientation being one of the main reasons behind the mediated gender gap. Again, there is no clear development over time regarding gender representation. We further find that female journalists systematically include more female sources than their male colleagues, irrespective of sector.

Figure 4 Gender distribution of quoted sources across source categories (per cent)

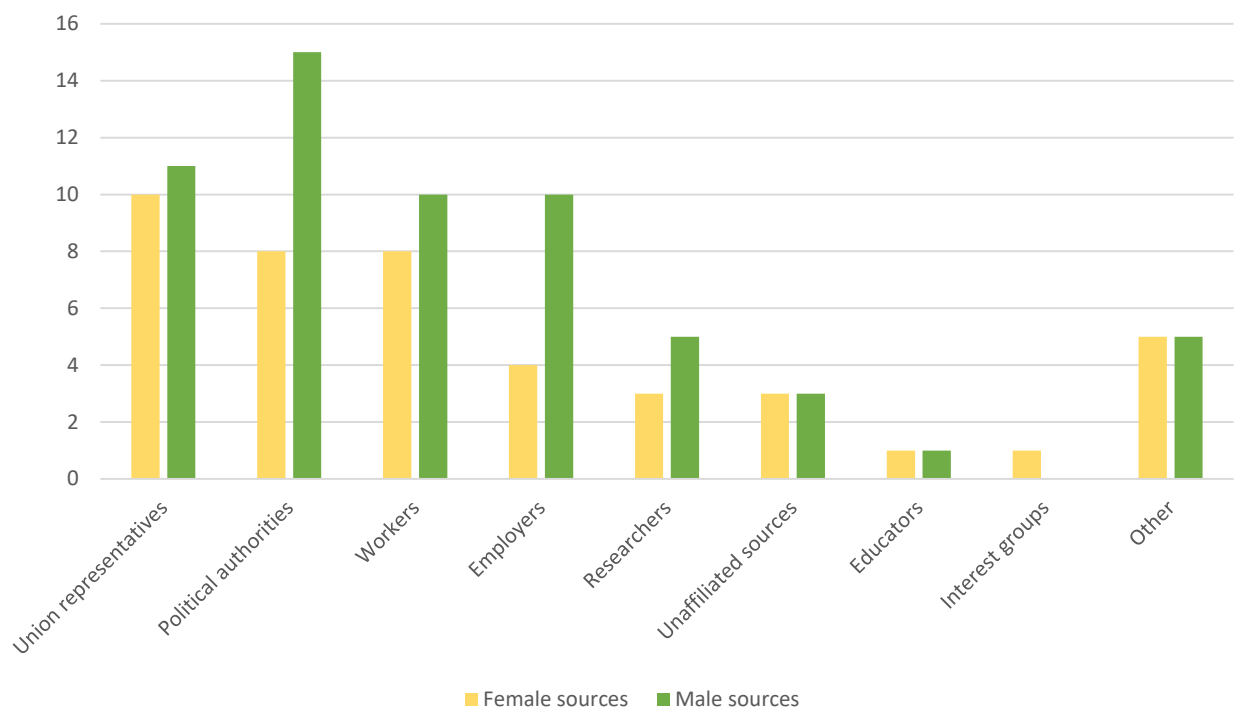

Comments: $N=1,377$ (in 12 cases, the gender of a news source could not be determined).

Of all quoted sources in the studied sample, people with ethnic minority backgrounds only make up 6 per cent of the sources $(84$ of 1,389). Sources with ethnic minority backgrounds are systematically underrepresented as news sources representing routine sources in the labour beat, mirroring the underrepresentation of ethnic minority representatives among societal elites. Overall, the main proportion of ethnic minority sources are found at the grassroots level among the care and construction workers themselves and 
among the non-affiliated sources ("ordinary people") interviewed. General Norwegian workforce statistics show that citizens with migrant backgrounds represent 16 per cent of all employees in the country. ${ }^{5}$ Thus, their representation among workers and ordinary people reflect the profound labour migration into the sectors studied.

If we compare the two sectors, sources with an ethnic minority background are distributed quite unevenly, as eight of ten interviewees with ethnic minority backgrounds work in the construction sector, while only two of ten work in the care sector. Although ethnic minorities are often vulnerable in both sectors, the care sector, as mostly municipal, may have a stricter system in place to regulate who gets to speak to the media about working conditions and other issues. In addition, when mapping ethnic background, the representation remains relatively stable over time, with a small increase in ethnic minority sources in 2006/2007, reflecting the EU enlargement. In 2016/2017, however, ethnic diversity returned to the 1990 s level, most probably reflecting the downscaling in newsrooms (see Eide \& Figenschou, 2021).

\section{Discussion}

In this article, we have analysed the representation of two traditional working-class sectors over a period of 20 years, and, in the following, we discuss the findings with insights from practitioners in the outlets studied and the existing academic literature.

Overall, we find that the construction and care sectors lose media salience throughout the period studied, and furthermore, that the character of the coverage changes from shorter news updates to fewer, more comprehensive and opinionated articles. From the content analysis alone, we cannot conclude whether the labour beat decreases relative to other specialised beats, or if the documented decline in coverage reflects a general transformation of newsrooms from specialised beats to digital generalists (see Magin \& Maurer, 2019).

Interviews with news editors and union press editors, however, offer insights from the practitioners' perspective: Overall, the interviewed editors explain that the labour beat - as a routinised practice with designated specialised reporters - has largely disappeared from established newsrooms. On the one hand, many stressed that labour was far from the only specialised beat to disappear over the past decades, primarily as a result of falling revenues and budget cuts (Eide \& Figenschou, 2021). Over the 20-year period studied, technological disruption and networked social media platforms have increased competition for attention, audiences, and advertisement. Consequently, as a result of falling revenues and failing business models, there has been a strong push towards cost-effective, popularised production (Karidi, 2018), giving rise to discussions of deprofessionalisation and deskilling in contemporary journalism (Gollmitzer, 2019). On the other hand, interviewees explained that the labour beat suffered particularly in these processes as it lost its momentum, while politics and finance - considered more prestigious and important - remained strongly prioritised in mainstream newsrooms. The editors explained that labour correspondents have retired (and not been replaced) or transferred to other beats or positions as general assignment reporters.

Overall, these insights confirm existing studies of the labour beat (see Bekken, 2005; Bjerke \& Fonn, 2016; Manning, 1998; Martin, 2019; Mathisen, 2013). However, the labour beat has again become relevant for two of the newspapers studied - Klassekampen 
(socialist left-leaning paper) and Dagsavisen (labour left-leaning paper) - as they received funding from the Norwegian Confederation of Trade Unions in 2016 to boost labour coverage. Furthermore, the middle-class orientation of contemporary news journalism was also highlighted as an explanation for diminishing attention to the labour movement in general and working class sectors in particular. Here, the editors disagreed: The trade union magazine editors and the news editors of the socialist paper underlined that social class, labour issues, and movement have become irrelevant to mainstream newspapers as a result of the professionalisation of journalism and consumer orientation in news production - what Hesmondhalgh (2017) labels the class asymmetry explanation - while the mainstream news editors interviewed argued that social class is irrelevant as an analytical lens to understand contemporary society.

Thematically, the analysis shows that traditional work-life journalism on workingclass sectors changes over time - from more informative coverage of working conditions to an emphasis on work-related conflicts and recruitment problems and lack of status for working-class craftsmanship and occupations. The development is not as dramatic as previous studies from other contexts and time periods indicate (e.g., Costain, 2005; Jacobsson \& Ekström, 2016; Manning, 1998), and there are only minor shifts in emphasis over time. From the content analysis, we cannot find a marked shift towards a more critical, negative coverage of the two sectors. It is more interesting here to note the differences between the mainstream newspapers - which stress working conditions, work-related conflicts, labour policy, and recruitment as their most covered topics - and the union press - which prioritise mostly working conditions and recruitment and to a lesser degree address work-related conflicts or labour policy. The mainstream newspapers emphasis on conflict and crises was criticised by the trade union magazine editors, who argued that the labour movement and workers are only deemed newsworthy if they can be framed in a negative way. Interviews with mainstream news editors found that the strong emphasis on conflict as news value is related to commercially driven news values, as newsworthiness in labour coverage is increasingly tied to major events (such as the annual wage settlements) and political, elite actors (such as the connections between the labour movement and the labour party) (for details, see Eide \& Figenschou, 2021). We do not find negative representations of the workers (employees in construction and care) either, as they are portrayed in a neutral manner in almost nine out of ten articles. Hence, contrary to international studies of neoliberal systems (e.g., Manning, 1998; Martin, 2019), Norwegian newspapers seem more uninterested than hostile to the labour movement in general and workers in particular (for further discussion, see Bjerke, 2016).

The analysis of sourcing hierarchies first confirms that the traditional stakeholders in the labour beat (union representatives, employers, and political authorities) remain dominant, and that there are few changes in these hierarchies over time. The importance of interviewing elite actors and stakeholders involved in major events was confirmed in the interviews, as source networks with decision-makers were stressed as essential (confirming the elite orientation found in previous studies; e.g., Manning, 1998, 2001). The editors largely explained the elite orientation by the fact that professional sources are more available, cost-efficient, and newsworthy for reporters working under great production pressure (Eide \& Figenschou, 2021).

In addition to the topical emphasis discussed above, it is the sourcing hierarchies that most effectively demonstrate the editorial differences between the mainstream 
newspapers and the trade union magazines, as the trade union magazines primarily talk to the labour movement (workers and union representatives). These sourcing practices reflect the trade union magazines' target audience (union members) and ownership (the unions), and trade union editors underlined that they repeatedly have to point out that they are not mouthpieces for the unions, but editorially independent as professional media organisations. At the same time, they underlined that they use the union network to gain access to both union representatives and members and workers (Eide \& Figenschou, 2021).

The mainstream newspaper editors described workers as less accessible than they used to be, largely unwilling to contribute, and migrant workers are particularly challenging to recruit due to a combination of factors (physical access, language barriers, fear of the media, and vulnerable positions). Overall, although they stressed the importance of interviewing the workers in the construction and care sectors, the editors underlined that actually getting them to speak is deemed too resource-demanding due to these hindrances, and that workers in the most vulnerable, precarious positions are almost impossible to access (Eide \& Figenschou, 2021). This corresponds with the content analysis, where we find that guest workers in the private sector may experience more insecurity, since many of them work at the mercy of contractors, which in itself is a conflictual issue. Workers in the care sector, as mostly municipal, may have a stricter system in place to regulate who gets to speak to the media about working conditions and other issues.

\section{Conclusion}

Studying 18 months of coverage of the construction and care sectors over a period of 20 years has provided insight into two broader issues: the representation of traditional working class sectors and workers in the media, and developments in the labour beat over a period characterised by deprofessionalisation, commercialisation, and disruption in the media sector.

Overall, supporting existing research, we find that the news interest in the care and construction sectors is declining as the labour beat has lost newsroom prestige, while the labour movement seems to be losing political momentum. At the same time, we do not find hostile coverage as seen in the US and UK. We identify attempts to revitalise the labour beat in mainstream newspapers, driven by economic incentives from the labour movement; and furthermore, the unions have introduced new media initiatives (online news, podcasts, etc.), which invite further analysis. Future studies should analyse how the labour movement communicates and competes for visibility in a crowded media landscape. Moreover, we must expand the focus to include newer working-class sectors beyond the archetypical factory worker (e.g., hairdressers, shop assistants, cleaners, domestic helpers, etc.). Such analysis could study whether media representations capture the changing composition of the contemporary working class (and hence supplement the classic labour-beat publications), and comparative studies in particular could provide insight into how these sectors are covered in different political and media systems.

The overall gender representation found in this study differs positively from other studies, although females are rarely represented in elite positions. Sources with ethnic minority backgrounds remain disproportionately low in all positions except as workers. 
Whether this is related to people of ethnic minority being in a more precarious positions as workers needs to be further explored.

Another intriguing question beyond the scope of this article is how and to what extent "the working class" and "workers" have become politicised issues (for examples, see Martin, 2019). We find some indications in our material, such as more opinion pieces and more debates concerning the status of the modern working class (e.g., on craftsmanship, social class, and recruitment to vocational education). As outlined in the beginning of this article, the populist wave and the political power of such large movements representing discontent and frustrated working-class people have served as a wake-up call for media organisations. Whether this implies more journalistic emphasis being dedicated to labour coverage and working people, or whether it primarily represents an elite debate on populism and the decline of social democracy in Norway and elsewhere in Europe, is a question worth examining in future studies.

\section{Notes}

1. Broadsheet not in the material sense; no Norwegian newspapers are broadsheet anymore.

2. In Norwegian, the construction sector sample was selected based on the following search terms: anleggsarb*, byg*, byggearb*, bygningsarb*, håndverker*, murer*, snekker*, tømrer*, and veiarb*. The care sector sample was generated by the search string: pleieassistent*, hjelpeassistent*, hjelpepleier*, pleiemedhjelper*, helsefagarbeider*, pleiemedarbeider*, and omsorgsarbeider*.

3. Cohen's kappa scores per variable are as follows: salience $(0.783)$, size $(0.907)$, genre $(0.867)$, source affiliation (0.891), source gender (0.918), source ethnicity (0.892), negative/positive portrayal or workers (0.705), and topical emphasis (0.834).

4. This topical framing was particularly prominent in the mainstream media around 2006/2007 due to the EU enlargement, as it triggered debates about social dumping and the potential undermining of labour conditions for the traditional (native-born) working class.

5. Statistics from late 2017 (https://www.ssb.no/innvregsys/, accessed 5 October 2018). Statistics Norway uses the following definition for this category: "migrants or Norwegian-born with migrant parents".

\section{References}

Allern, S., \& Pollack, E. (2019). Journalism as a public good: A Scandinavian perspective. Journalism, 20(11), 1423-1439. https://doi.org/10.1177\%2F1464884917730945

Bekken, J. (2005). The invisible enemy: Representing labour in a corporate media order. Javnost - The Public, 12(1), 71-84. https://doi.org/10.1080/13183222.2005.11008883

Bennett, L. (1990). Toward a theory of press-state relations in the United States. Journal of Communication, 40(2), 103-127. https://doi.org/10.1111/j.1460-2466.1990.tb02265.x

Berkowitz, D. A. (2009). Reporters and their sources. In K. Wahl-Jorgensen, \& T. Hanitzsch (Eds.), The Handbook of Journalism Studies (pp. 59-72). New York: Routledge.

Biressi, A. (2018). 'Everything changes. Everything stays the same': Documenting continuity and change in working class lives. In D. O’Neill, \& M. Wayne (Eds.), Considering class: Theory, culture and the media in the 21st century (pp. 237-255). Boston: Brill. https://doi.org/10.1163/9789004319523

Bjerke, P. (2016). Arbeidslivs- eller forbrukerjournalistikk? [Working life or consumer journalism?]. In P. Bjerke, B. K. Fonn, \& E. S. Strømme (Eds.), Økonomijournalistikk: Perspektiver og metoder. [Economy journalism: Perspectives and methods] (pp.105-125). Bergen: Fagbokforlaget.

Bjerke, P., \& Fonn, B. K. (2016). Økonomi og journalistikk: et samspill [Economy and journalism as coplayers]. In P. Bjerke, B. K. Fonn, \& E. S. Strømme (Eds.), Økonomijournalistikk: Perspektiver og metoder [Economy journalism: Perspectives and methods] (pp. 21-41). Bergen: Fagbokforlaget.

Bohlin, R. (2012). De osynliga: Om Europas fattiga arbetarklass [The invisible: Europe's working poor]. Stockholm: Atlas Reportage.

Brüggemann, M., Engesser, S., Büchel, F., Humprecht, E., \& Castro, L. (2014). Hallin and Mancini revisited: Four empirical types of Western media systems. Journal of Communication, 64(6), 1037-1065. https:// doi.org/10.1111/jcom. 12127

Costain, G. (2005). Reporting on labour: Class consciousness and the uncertain ideological boundaries of Canadian journalism. Javnost - The Public, 12(1), 49-69. https://doi.org/10.1080/13183222.2005.11008882 
Crenshaw, K. (1989). Demarginalizing the intersection of race and sex: A Black feminist critique of antidiscrimination doctrine, feminist theory and antiracist politics. University of Chicago Legal Forum, 1989, 139-167. https://heinonline.org/HOL/P?h=hein.journals/uchclf1989\&i=143

Eide, E. (2011). Down There and Up Here: Orientalism and othering in feature stories. New York: Hampton Press.

Eide, E., \& Figenschou, T. U. (2021). Arbeidsliv, arbeidsfolk og klasse i norske aviser [Working life, working people and class in Norwegian newspapers]. In J. Ljunggren, \& M. N. Hansen (Eds.), Arbeiderklassen [The working class] (pp. 331-351). Oslo: Cappelen Damm Akademisk.

Eide, E., \& Orgeret, K. S. (Eds.). (2015). Etter beste kjønn: Kjønnsperspektiver på medier og journalistikk [Gender perspectives on media and jouralism]. Oslo: Scandinavian University Press.

Eide, M., \& Knight, G. (1999). Public/private service: Service journalism and the problems of everyday life. European Journal of Communication, 14(4), 525-547. https://doi.org/10.1177/0267323199014004004

Gerbner, G., \& Gross, L. (1976). Living with television: The violence profile. Journal of Communication, 26(2), 172-199. https://doi.org/10.1111/j.1460-2466.1976.tb01397.x

Gollmitzer, M. (2019). Employment conditions in journalism. Oxford Research Encyclopedia of Communication. https://doi.org/10.1093/acrefore/9780190228613.013.805

Grace, T. (1985). The trade-union press in Britain. Media, Culture \& Society, 7, 233-255.

Gressgård, M. (2008). Mind the Gap: Intersectionality, Complexity and 'the Event', Theory and Science, 10(1).

Haakestad, H., \& Friberg, J. H. (2020). Deskilling revisited: Labour migration, neo-Taylorism and the degradation of craft work in the Norwegian construction industry. Economic and Industrial Democracy, 41(3), 630-651. https://doi.org/10.1177/0143831X17735671

Hall, S., Critcher, C., Jefferson, T., Clarke, J., \& Roberts, B. (1978). Policing the crisis: Mugging, the state and law and order. London: Palgrave Macmillan.

Hallin, D. C. (1989). 'Uncensored war': The media and Vietnam (with a new preface). Berkley, California: University of California Press. (Original work published 1986)

Hallin, D. C., \& Mancini, P. (2004). Comparing media systems: Three models of media and politics. New York: Cambridge University Press.

Hesmondhalgh, D. (2017). The media's failure to represent the working class: Explanations from media production and beyond. In J. Deery, \& A. Press (Eds.), Media and class: TV, film and digital culture (pp. 21-37). New York: Routlegde. https://doi.org/10.4324/9781315387987

Ihlen, Ø., Skogerbø, E., \& Allern, S. (Eds.). (2015). Makt, medier og politikk: Norsk politisk kommunikasjon [Power, media and politics: Norwegian political communication]. Oslo: Scandinavian University Press.

Jacobsson, D., \& Ekström, M. (2016). Dismantling discourses: Compassion, coping and consumption in journalistic representations of the working class. Critical Discourse Studies, 13(4), 379-396. https:// doi.org/10.1080/17405904.2015.1122644

Jakobsson, P., \& Stiernstedt, F. (2018). Naturalizing social class as a moral category on Swedish mainstream television. Nordicom Review, 39(1), 81-94. https://doi.org/10.2478/nor-2018-0003

Kalsnes, B., \& Steensen, S. (2020). Fra fast lokaljournalist til midlertidig digitalt hode [From permanently hired local journalist to temporary digital head]. Norsk Medietidsskrift, 107(1), 1-19.

Karidi, M. (2018). New media on the move? Journalism Studies, 19(9), 1237-1256. https://doi.org/10.1080 /1461670X.2016.1266281

Krippendorff, K. (2018). Content analysis: An introduction to its methodology. London: Sage.

Lecheler, S., \& Kruikemeier, S. (2016). Re-evaluating journalistic routines in a digital age: A review of research of the use of online sources. New Media and Society, 18(1), 156-171. https://doi. org/10.1177/1461444815600412

Lindell, J. (2018). Distinction recapped: Digital news repertoires in the class structure. New Media \& society, 20(8), 3029-3049. https://doi.org/10.1177/1461444817739622

Magin, M., \& Maurer, P. (2019). Beat journalism and reporting. Oxford Research Encyclopedia of Communication. https://doi.org/10.1093/acrefore/9780190228613.013.905

Manning, P. (1998). Spinning for labour: Trade unions and the new media environment. Routledge. https:// doi.org/10.4324/9780429438271

Manning, P. (2001). News and news sources: A critical introduction. London: Sage.

Martin, C. R. (2019). No nonger Newsworthy: How the mainstream media abandoned the working class. London: Cornell University Press.

Mathisen, B. R. (2013). Gladsaker og suksesshistorier: En sosiologisk analyse av lokal naringslivsjournalistikk I spenning mellom lokalpatriotisme og granskningsoppdrag [Success stories: A sociological analysis of local business] [Doctoral thesis, Nord University, Bodø, Norway]. http://hdl.handle.net/11250/139942

Ohlsson, J. (2015). The Nordic media market. Gothenburg: Nordicom, University of Gothenburg.

Orupabo, J. (2016). Kvinnejobber, mannsjobber og innvandrerjobber [Women's jobs, men's jobs and immigrants'jobs]. Oslo: Cappelen Damm Akademisk. 
Phillips, A. (2010). Old sources: New bottles. In N. Fenton (Ed), New media, old news: Journalism and democracy in the digital age (pp. 87-101). London: Sage.

Rommetvedt, H. (2017). Scandinavian corporatism in decline. In O. Knudsen (Ed.), The Nordic models in political science: Challenged, but still viable? (pp.171-190). Bergen: Fagbokforlaget.

San Martin, V. C. (2019). The mediated representation of working conditions in the Global South discourse, ideology and responsibility [Doctoral Thesis, Örebro University, Sweden]. http://urn.kb.se/ resolve?urn=urn:nbn:se:oru:diva-74667

Stiernstedt, F., \& Jakobsson, P. (2018). Voice, silence and social class on television. European Journal of Communication, 33(5), 522-539. https://doi.org/10.1177/0267323118784819

Syvertsen, T., Enli, G., Mjøs, O. J., \& Moe, H. (2014). The media welfare state: Nordic media in the digital era. Ann Arbor, Michigan: University of Michigan Press. https:/www.doi.org/10.3998/ nmw.12367206.0001.001

Tuchman, G. (1978). Hearth and home: Images of women and the media. New York: Oxford University Press. Tvedt, T. (2003). Utviklingshjelp, utenrikspolitikk og makt: Den norske modellen [Development assistance, foreign policy and power: The Norwegian model]. Oslo: Gyldendal Akademisk,

Yilmaz, F. (2018). From class solidarity to cultural solidarity: Immigration, crises, and the populist right. In D. O'Neill, \& M. Wayne (Eds.), Considering class: Theory, culture and the media in the 21st century (pp. 198-217). Boston: Brill. https://doi.org/10.1163/9789004319523

(C) 2021 Nordicom and respective authors. This is an Open Access work licensed under the terms of the Creative Commons Attribution-NonCommercial-NoDerivatives 4.0 International Public licence (CC BY-NC-ND 4.0). To view a copy of the licence, visit https://creativecommons.org/ licenses/by-nc-nd/4.0/ 